\title{
Altered expression of mir-222 and mir-25 influences diverse gene expression changes in transformed normal and anaplastic thyroid cells, and impacts on MEK and TRAIL protein expression
}

\author{
SINÉAD T. AHERNE ${ }^{1}$, PAUL SMYTH ${ }^{2}$, MICHAEL FREELEY $^{3}$, LEILA SMITH $^{4}$, \\ CATHY SPILLANE ${ }^{2}$, JOHN O'LEARY ${ }^{2}$ and ORLA SHEILS ${ }^{2}$ \\ ${ }^{1}$ National Institute for Cellular Biotechnology, Dublin City University, Glasnevin, Dublin 9; \\ ${ }^{2}$ Department of Histopathology; ${ }^{3}$ Department of Clinical Medicine and \\ Trinity Translational Medicine Institute, Trinity College Dublin, Dublin 8, Republic of Ireland; \\ ${ }^{4}$ Fluidigm Corporation, Suite 100, South San Francisco, CA 94080, USA
}

Received January 9, 2016; Accepted March 21, 2016

DOI: $10.3892 /$ ijmm.2016.2653

\begin{abstract}
Thyroid cancer is the most common endocrine malignancy and accounts for the majority of endocrine cancerrelated deaths each year. Our group and others have previously demonstrated dysfunctional microRNA (miRNA or miR) expression in the context of thyroid cancer. The objective of the present study was to investigate the impact of synthetic manipulation of expression of miR-25 and miR-222 in benign and malignant thyroid cells. miR-25 and miR-222 expression was upregulated in $8505 \mathrm{C}$ (an anaplastic thyroid cell line) and Nthy-ori (a SV40-immortalised thyroid cell line) cells, respectively. A transcriptomics-based approach was utilised to identify targets of the two miRNAs and real-time PCR and western blotting were used to validate a subset of the targets. Almost 100 mRNAs of diverse functions were found to be either directly or indirectly targeted by both miR-222 and miR-25 [fold change $\geq 2$, false discovery rate (FDR) $\leq 0.05$ ]. Gene ontology analysis showed the miR-25 gene target list to be significantly enriched for genes involved in cell adhesion. Fluidigm real-time PCR technologies were used to validate the downregulation of 23 and 22 genes in response to miR-25 and miR-222 overexpression, respectively. The reduction of the expression of two miR-25 protein targets, TNF-related
\end{abstract}

Correspondence to: Dr Sinéad T. Aherne, National Institute for Cellular Biotechnology, Dublin City University, Collins Avenue, Glasnevin, Dublin 9, Republic of Ireland

E-mail: sinead.aherne@dcu.ie

Abbreviations: MAPK, mitogen-activated protein kinase; hTERT, human telomerase reverse transcriptase; FDR, false discovery rate; RIPA, radioimmunoprecipitation assay; DR4, TRAIL death receptor-4; PSG, pregnancy-specific glycoprotein; TRAIL, TNF-related apoptosisinducing ligand; IKK complex, inhibitor of $\kappa \mathrm{B}$ kinase complex; ERK, extracellular regulated kinases; JNK, c-Jun NH2-terminal kinase

Key words: thyroid cancer, miR-222 and miR-25, microarray, target genes, mitogen-activated protein kinase kinase 4 and TNF-related apoptosis-inducing ligand apoptosis-inducing ligand (TRAIL) and mitogen-activated protein kinase kinase 4 (MEK4), was also validated. Manipulating the expression of both miR-222 and miR-25 influenced diverse gene expression changes in thyroid cells. Increased expression of miR-25 reduced MEK4 and TRAIL protein expression, and cell adhesion and apoptosis are important aspects of miR-25 functioning in thyroid cells.

\section{Introduction}

Thyroid cancer is the most common endocrine malignancy, and incidences are on the rise worldwide. Thyroid tumours frequently possess genetic alterations which lead to the activation of the mitogen-activated protein kinase (MAPK) signalling pathway (1). The expression of microRNAs (miRNAs or miRs) has been studied in thyroid cancers, and as with other types of cancer, miRNA profiles have been found to be significantly different between tumours of the thyroid compared to normal thyroid tissue. For instance miR-146, miR-221, miR-222, miR-155, miR-181a and miR-181b have been shown to differentiate papillary thyroid cancer from normal thyroid tissue $(2,3)$.

miRNAs have also shown differential expression between different types of thyroid cancer (4) and within a multifocal pluriform tumour from an individual thyroid gland (5), thus illustrating that miRNA profiles have demonstrated both intraand inter-tumour variability. The functions of some of these differentially expressed miRNAs have also been elucidated: for instance, miR-221 has been shown to regulate HOXB5 (6) and the human telomerase reverse transcriptase ( $h T E R T)$ gene is regulated by miR-138 (7). Furthermore, the potential utility of these small molecules to aid thyroid cancer diagnosis (8) and prognosis (9) has also been investigated.

The aim of the present study was to elucidate the target mRNAs of two miRNAs that we had previously found to be differentially expressed in thyroid cancer (5): miR-222 and miR-25. miR-222 is commonly found to be upregulated in thyroid cancer (2-4) and is part of an intergenic miRNA cluster (that also contains miR-221) on the p11.3 region of the X chromosome. It is one of the most well-known miRNAs linked to 
thyroid cancer, and some of its gene targets have been elucidated, including the KIT gene (2) and the $\mathrm{p} 27^{\mathrm{Kipl}}$ protein (10).

miR-25 is also located in a miRNA cluster, termed the mi-106b-25 cluster. miR-106b and miR-93 are the two other miRNAs in this highly conserved cluster which is located in a 515-bp region at chromosome $7 q 22$, in intron 13 of the host gene $M C M 7$. The miRNAs are co-transcribed in the context of the $M C M 7$ primary transcript and have been found to accumulate in different types of cancer, including gastric, prostate, pancreatic neuroendocrine tumours, neuroblastoma and multiple myeloma (11). $\mathrm{miR}-25$ has been shown to regulate p57 (12) and E2F1 as part of a negative feedback loop in gastric cancer (11). It has also been shown to promote cell invasion and migration in esophageal squamous cell carcinoma (13) and regulate apoptosis by targeting the Bim protein in ovarian (14) and eosophangeal cells (15). miR-25 has been found to be downregulated in anaplastic thyroid carcinoma (16) and, along with miR-30d, to target the polycomb protein enhancer of zeste 2 (EZH2) in this disease context (17).

In this study, we describe work in which we examined the impact of upregulating the thyroid cancer-associated miRNA miR-222 in benign Nthy-ori cells, and miR-25, a miRNA downregulated in anaplastic thyroid cancer, in the anaplastic cancer-derived $8505 \mathrm{C}$ cell line. Microarray technologies were utilised to monitor global gene expression changes in response to altered expression of miR-222 and miR-25. This unbiased genome-wide approach provided by the microarrays yielded the discovery of almost 100 mRNAs that are either directly or indirectly targeted by each miRNA in thyroid cells and have not been previously described to the best of our knowledge. These gene lists provide insights as to the functions of these miRNAs within thyroid cells; they contain both predicted and novel targets of the miRNAs, a subset of which were validated at the mRNA and protein level.

\section{Materials and methods}

Cell culture. The human thyroid follicular epithelial cell line Nthy-ori 3-1 (cat no. 90011609; ECACC, Salisbury, UK) was grown in RPMI media containing $10 \%$ foetal bovine serum (FBS), $2 \%$ penicillin/streptomycin $(5,000 \mathrm{U} / \mathrm{ml})$. An undifferentiated human thyroid carcinoma cell line, $8505 \mathrm{C}$, (cat no. 94090184; ECACC) was grown in Eagle's minimum essential medium (EMEM) with Hank's buffered salt solution (HBSS) containing $2 \mathrm{mM}$ glutamine and $1 \%$ non-essential amino acids (NEAA), $10 \% \mathrm{FBS}$, and $2 \%$ penicillin/streptomycin $(5,000 \mathrm{U} / \mathrm{ml})$. All cell culture reagents were purchased from Lonza (Basel, Switzerland) and cells were incubated at $37^{\circ} \mathrm{C}$ in a $5 \% \mathrm{CO}_{2}$ humidified chamber (series II water jacketed $\mathrm{CO}_{2}$ incubator; Thermo Fisher Scientific, Waltham, MA, USA).

Transfections. For transfections, Nthy-ori 3-1 and 8505C cells were plated at a density of $1.5 \times 10^{5}$ cells $/ \mathrm{ml}$ in 12 -well plates (Nalge Nunc, Penfield, NY, USA) with three replicate wells for each condition. Cells were reverse transfected using Lipofectamine 2000 (Invitrogen, Grand Island, NY, USA) according to the manufacturer's instructions with $50 \mathrm{nM}$ pre-miR positive control (cat. \# AM17150), pre-miR negative control \#1 (cat. \# AM17110), pre-miR-222 (cat. \# PM11376) or pre-miR-25 (cat. \# PM12401) (Ambion, Austin, TX, USA).
Transfection efficiency was evaluated using TaqMan real-time polymerase chain reaction (PCR) as follows. Pre-miR hsa-miR-1 miRNA precursor was used as a positive control in transfection experiments as, upon delivery into cells, it effectively downregulates the expression of $P T K 9$ at the mRNA level. Effective delivery and activity of the pre-miR hsa-miR-1 miRNA precursor was detected by real-time PCR using a TaqMan Gene Expression assay to PTK9 (assay ID: Hs00702289_s1), and GAPDH mRNA was measured as an endogenous control (assay ID: Hs02758991_g1) (both from Applied Biosystems, Foster City, CA, USA). A high capacity cDNA reverse transcription kit (cat. \# 4374966; Applied Biosystems) was used to convert total RNA to single-stranded cDNA for positive control analysis. Reactions contained $2 \mu \mathrm{l}$ of RT buffer (10X), $0.8 \mu \mathrm{l}$ of deoxynucleotide triphosphate (25X), $2 \mu \mathrm{l}$ of random primers (10X), $1 \mu \mathrm{l}$ of multiscribe RT enzyme (500 U/ $\mu \mathrm{l}), 1 \mu \mathrm{l}$ of RNase inhibitor, $3.2 \mu \mathrm{l}$ of nuclease-free water and $10 \mu \mathrm{l}$ of extracted total RNA. The reactions were incubated at $25^{\circ} \mathrm{C}$ for $10 \mathrm{~min}, 37^{\circ} \mathrm{C}$ for $2 \mathrm{~h}$, and $85^{\circ} \mathrm{C}$ for $5 \mathrm{sec}$ (Perkin Elmer 9600 GeneAmp PCR system; Applied Biosystems). Real-time PCR reactions were performed with TaqMan 2X Universal master mix (no AmpErase UNG) (cat. \# 4304437; Applied Biosystems) and TaqMan gene expression assays (listed previously). Reactions contained $10 \mu \mathrm{l}$ of TaqMan Universal PCR master mix (no AmpErase UNG), $1 \mu 1$ of TaqMan gene expression assay (20X), $2 \mu \mathrm{l}$ of cDNA template and $7 \mu \mathrm{l}$ of nuclease-free water.

For miRNA analysis, total RNA from transfections was used to synthesise cDNA using the high-capacity cDNA reverse transcription kit and miRNA-specific RT primers for miR-222 (cat. \# 4427975), miR-25 (cat. \# 4427975), and endogenous control RNU6B (cat. \# 4427975) (Applied Biosystems) in $15 \mu 1$ reactions. Reactions contained $0.15 \mu \mathrm{l}$ of $25 \mathrm{X}$ dNTP mixture (100 mM), $1 \mu \mathrm{l}$ of multiScribe reverse transcriptase $(50 \mathrm{U} / \mu \mathrm{l})$, $1.5 \mu \mathrm{l}$ of reverse transcription buffer (10X), $0.19 \mu \mathrm{l}$ of RNase inhibitor, $4.16 \mu \mathrm{l}$ of nuclease-free water, $3 \mu \mathrm{l}$ of RT primer and $5 \mu \mathrm{l}$ of extracted total RNA. The reactions were incubated at $16^{\circ} \mathrm{C}$ for $30 \mathrm{~min}, 42^{\circ} \mathrm{C}$ for $30 \mathrm{~min}, 85^{\circ} \mathrm{C}$ for $5 \mathrm{~min}$ and then an indefinite hold at $4^{\circ} \mathrm{C}$ (Perkin Elmer 9600 GeneAmp PCR system; Applied Biosystems). miRNA expression was then assessed using sequence specific primers from the TaqMan microRNA assays and TaqMan 2X Universal master mix (no AmpErase UNG) (cat. \# 4304437; Applied Biosystems) in $20 \mu 1$ reactions according to the manufacturer's instructions. Reactions contained $1 \mu \mathrm{l}$ of TaqMan miRNA assay mix (20X), $1.33 \mu \mathrm{l}$ of product from RT reaction (1:15 dilution), $10 \mu \mathrm{l}$ of TaqMan 2X Universal master mix (no AmpErase UNG) and $7.67 \mu 1$ of nuclease free water. Each assay was performed in triplicate for each sample.

All real-time PCR reactions were incubated in a 96-well optical plate (cat. \# N8010560; Applied Biosystems) at $95^{\circ} \mathrm{C}$ for $10 \mathrm{~min}$, following by 40 cycles of $95^{\circ} \mathrm{C}$ for $15 \mathrm{sec}$ and $60^{\circ} \mathrm{C}$ for $1 \mathrm{~min}$ on the Applied Biosystems 7900HT Real-Time PCR system (Applied Biosystems). Study files were generated using a fixed threshold of 0.1 on the SDS2.2.2 software (Applied Biosystems), and Microsoft Excel (Microsoft, Redmond, WA, USA) was used to perform $\Delta \Delta \mathrm{Ct}$ analysis on the real-time PCR output (18).

RNA isolation and mRNA microarray analysis. Total RNA was isolated from transfected cell lines using PARIS ${ }^{\text {TM }}$ Protein 
and RNA isolation kit (cat. \# AM1556; Ambion) and RNeasy mini kit (cat. \# 74104; Qiagen, Venlo, The Netherlands). Briefly, the cells were lysed with PARIS Cell Disruption Buffer and 2X Lysis/Binding Solution. Cell lysates were then transferred to Qiagen QIAshredder columns followed by RNA extraction and on column DNase treatment (Cat. \# 79254; Qiagen, Venlo, The Netherlands) according to the manufacturer's instructions. RNA nanogram concentration per microlitre was verified using a NanoDrop spectrophotometer (ND-1000; Labtech International, Lewes, UK) and RNA integrity was verified using a 2100 Bioanalyser (Agilent, Santa Clara, CA, USA).

Affymetrix GeneChip Human Gene 1.0 ST arrays were used for gene expression analysis according to the manufacturer's instructions (cat. \# 902461; Affymetrix, Santa Clara, CA, USA). Three biological repeats were used for each treatment. Microarray statistical analysis was performed on .CEL files using the Partek Genomics Suite (Partek Inc., St. Louis, MO, USA; www.partek.com). Data were normalised and summarised using the robust multi-average method, as previously described (19). Paired t-tests were performed to compare the data from the pre-miR transfections to the negative control transfections. Comparisons were corrected for multiple testing using the false discovery rate (FDR). Genes were deemed to be differentially regulated in the pre-miR ${ }^{\mathrm{TM}}$ transfected cells if they possessed a FDR $\leq 0.05$ and a fold change $\geq 2$. Gene functional and pathway enrichment analysis was assessed by the PANTHER database (http://www.pantherdb.org/).

Fluidigm reverse transcription-PCR analysis of target genes downregulated by $m i R-222$ and $m i R-25$. Total RNA from transfections was converted to single-stranded cDNA using the High Capacity cDNA Reverse Transcription kit (cat. \# 4374966; Applied Biosystems) in $20 \mu 1$ reactions, as described in the transfection section of this manuscript.

Pre-amplification of cDNA was performed using the TaqMan PreAmp Master Mix kit (cat. \# 4384267; Applied Biosystems). The assays used were as follows: MAL2; Hs00294541_m1, MAL; Hs00242748_m1, TLR3; Hs01551078_m1, ADM; Hs00181605_m1, RAB19; Hs01397748_m1, PDCD1LG2; Hs00228839_m1, RAD51; Hs00947968_m1, ADAM21; Hs01652548_s1, HYOU1; Hs01026180_m1, THBS1; Hs00962908_m1, ETS1; Hs00428287_m1, FGFR2; Hs03466165_gH, CYR61; Hs00609994_m1, PHLDB2; Hs01083801_m1, BIRC3; Hs00154109_m1, PRKAA2; Hs00178903_m1, CYP24A1; Hs00989011_g1, AOX1; Hs00154079_m1, MYO5C; Hs00218921_m1, GPR126; Hs01097890_m1, CDK6; Hs00608037_m1, PPME1; Hs00211693_m1,RBM24; Hs00290607_m1,TNFSF10/TRAIL; Hs00921974_m1, ITGA6; Hs01041012_m1, MPP1; Hs00609971_m1, TIMP2; Hs00234278_m1, ITGA3; Hs01076876_m1, ADAMTS1; Hs00199608_m1, ITGA5; Hs00233732_m1, TRIP13; Hs01020073_m1, MAP2K4; Hs00387426_m1, RAB23; Hs00212407_m1, ADAM10; Hs00153853_m1, TRHDE; Hs00183821_m1, RAB14; Hs00249440_m1, RARB; Hs00233405_m1, MAN2A1; Hs00159007_m1, RGS4; Hs00194501_m1, PTGS2; Hs00153133_m1, EPGN; Hs02385425_m1, SNAP23; Hs01047498_m1, LHFPL2; Hs00299613_m1, MYO1B; Hs01031676_m1, NFIA; Hs00906448_m1, RNF38; Hs01014398_ml (all from Applied Biosystems). Before running the pre-amplification reaction, the intended assays were pooled together, as per the manufacturer's instructions, with $1 \mathrm{X}$ TrisEDTA (TE) buffer in a $0.2 \mathrm{X}$ pooled assay mix. The pre-amplification reaction was performed in $5 \mu \mathrm{l}$ reactions containing $2.5 \mu \mathrm{l}$ of TaqMan PreAmp master mix (2X), $1.25 \mu \mathrm{l}$ of the pooled assay mix (0.2X), and $1.25 \mu \mathrm{l}$ of cDNA sample (100 ng). The pre-amplification reaction was performed for $10 \mathrm{~min}$ at $95^{\circ} \mathrm{C}$, and 14 cycles of $15 \mathrm{sec}$ at $95^{\circ} \mathrm{C}$ and $4 \mathrm{~min}$ at $60^{\circ} \mathrm{C}$ (PE 9600 GeneAmp PCR system; Applied Biosystems).

The Fluidigm Dynamic Arrays facilitate the testing of the expression of 48 genes in 48 samples by performing 2,304 PCR assays per chip. The TaqMan gene expression assays listed in the previous paragraph were diluted to a final concentration of 10X using Fluidigm DA Assay Loading Reagent (cat. \# 100-7611; Fluidigm, South San Francisco, CA, USA), and the pre-amplified products, diluted to 1:5 using $1 \mathrm{X}$ TE buffer. The cDNA product was combined with real-time PCR reagents in $5 \mu \mathrm{l}$ reactions as follows: $2.25 \mu \mathrm{l}$ of diluted pre-amplified cDNA, $2.25 \mu 1$ Universal PCR master mix (2X) (cat. \# 4304437; Applied Biosystems), and $0.25 \mu$ l Fluidigm sample loading agent (cat. \# 100-7610; Fluidigm). Samples, primers and probes were then loaded onto the Fluidigm 48.48 Dynamic Arrays and placed on the IFC controller (both from Fluidigm) which pressure-loads the assay components into the reaction chambers. Assay components are automatically combined on-chip. The Biomark Real-Time PCR system (Fluidigm) was then used for thermal cycling and fluorescence detection. cDNA from transfections was loaded in duplicate on three replicate dynamic arrays. Microsoft Excel (Microsoft) was used to perform $\Delta \Delta \mathrm{Ct}$ analysis on the real-time PCR output, as previously described (18).

Protein extraction and western blotting. Protein was isolated from transfections using ice-cold radioimmunoprecipitation assay (RIPA) buffer (cat. \# R0278; Medical Supply Co., Dublin, Ireland) with added protease and phosphatase inhibitor cocktails (cat. \# 04693116001 and 04693116001 respectively; Roche, Indianapolis, IN, USA). Samples were suspended in SDS-PAGE sample buffer (cat. \# S3401; Sigma-Aldrich, St. Louis, MO, USA), boiled for $4 \mathrm{~min}$, and resolved on $10 \%$ SDS-PAGE gels. The separated proteins were electrophoretically transferred to PVDF membranes by the semi-dry transfer technique for $1 \mathrm{~h}$. PVDF membranes were subsequently blocked in 5\% non-fat dried milk in TBS-0.1\% Tween-2 (TBS-T) for $1 \mathrm{~h}$ at room temperature, washed three times in TBS-T, and incubated with primary antibodies (polyclonal rabbit anti-human mitogenactivated protein kinase kinase 4 (MEK4) (sc-964; Santa Cruz Biotechnology, Inc., Santa Cruz, CA, USA) diluted to 1:50, or monoclonal mouse anti-human TNF-related apoptosis-inducing ligand (TRAIL) (ab12124) at $2 \mu \mathrm{g} / \mathrm{ml}$, or monoclonal mouse anti-human GAPDH (ab8245) (diluted to 1:25,000) (both from Abcam, Cambridge, UK) overnight at $4^{\circ} \mathrm{C}$ with gentle rocking. After three washes in TBS-T, the membranes were incubated with the appropriate HRP-labelled secondary antibodies [goat anti-mouse IgG-HRP, goat anti-rabbit IgG-HRP (cat. \# 7076 and 7074 respectively; Cell Signaling Technology, Danvers, MA, USA)] for $1 \mathrm{~h}$ at room temperature. The membranes were washed three times in TBS-T and immunoreactive bands were visualised using a HRP development solution containing $100 \mathrm{mM}$ Tris- $\mathrm{HCl} \mathrm{pH} 8.8,30 \% \mathrm{H}_{2} \mathrm{O}_{2}, 250 \mathrm{mM}$ luminol, and $90 \mathrm{mM}$ 
A

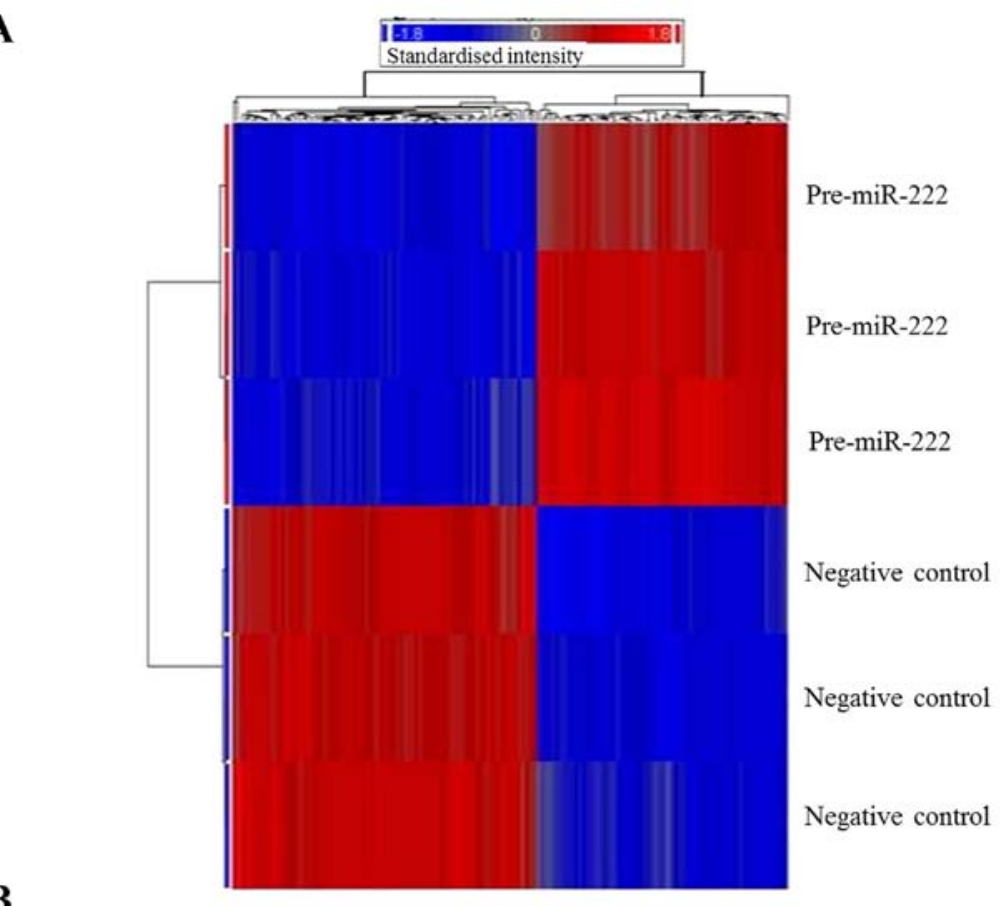

B

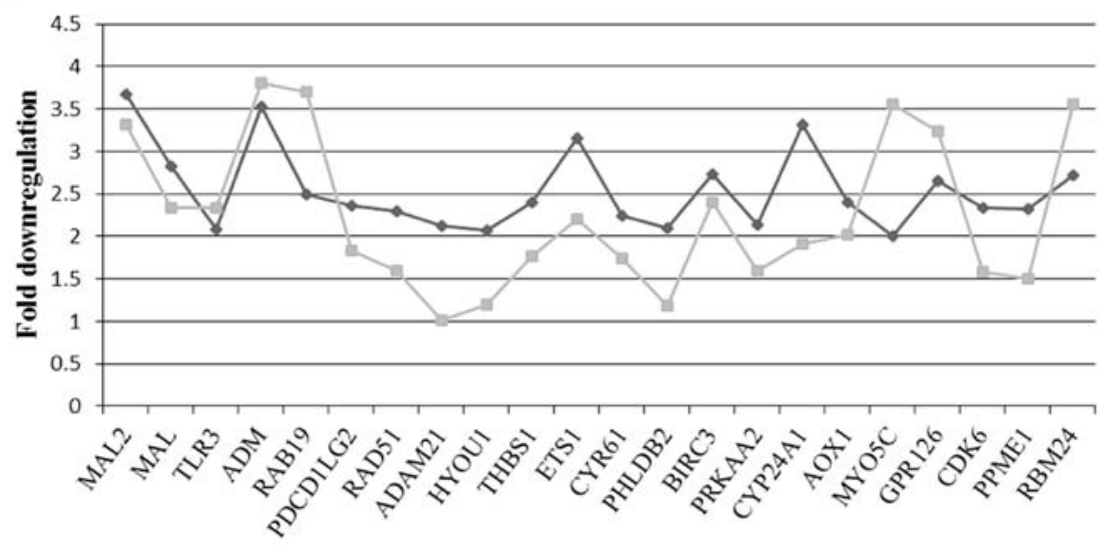

Gene name

$\rightarrow-$ Microarray fold downregulation $\quad \rightarrow-$ Fluidigm fold downregulation

Figure 1. miR-222 regulated genes. (A) Heat map of the significantly differentially regulated genes in pre-miR-222 treated Nthy-ori cells compared to negative control treated cells, false discovery rate (FDR) $\leq 0.05$ and fold-change $\geq 2$. A clear separation can be seen between the genes in pre-miR treated samples compared to negative control treated samples. (B) Line graph of the microarray and Fluidigm fold downregulation of the 22 genes validated by real-time PCR. All genes validated were found to be downregulated by both real-time PCR and microarray analyses (Pearson's correlation, 0.506).

4-iodophenylboronic acid (4-IPBA), and subsequent exposure to Kodak light-sensitive film (cat. \# F5763-50EA; Sigma-Aldrich). Jurkat $\mathrm{T}$ cell lysates were a gift from Dr Michael Freeley and were used as postive control lysates in western blot experiments

\section{Results}

As has been previously noted, expression of miR-222 is upregulated in thyroid cancers compared to their normal counterparts (2-5), while expression of miR-25 is downregulated in anaplastic thyroid carcinoma $(5,16)$. We therefore investigated the impact of overexpression of miR-222 in normal Nthy-ori cells, and of miR-25 in the $8505 \mathrm{C}$ cells. An average 2.9-fold upregulation of miR-222 and 10,939fold upregulation of miR-25 was observed with the pre-miR transfections $(n=3)$. The very large miR-25 fold change increase resulted from an average $\mathrm{Ct}$ change of 20.95 in the pre-miR-25 treated cells compared to 33.53 in the cells treated with the negative control pre-miR. Reduced transfection efficiency in the normal Nthy-ori cells may explain the more modest increase in miR-222 post-transfection; however, the positive control gene, PTK9, was downregulated to a similar extent in both cell lines; 82.9 and $76.9 \%$ in the $8505 \mathrm{C}$ and Nthy-ori cells respectively. Microarray analysis elucidated the genes significantly downregulated (FDR value $\leq 0.05$ and fold-change $\geq 2$ ) by pre-miR-222 in Nthy-ori cells and pre-miR-25 in $8505 \mathrm{C}$ cells. We found that overexpression of miR-222 in normal Nthy-ori cells resulted in the downregulation of 82 target genes, while overexpression of miR-25 resulted in the downregulation of 98 target genes in $8505 \mathrm{C}$ cells. Figs. $1 \mathrm{~A}$ and $2 \mathrm{~A}$ illustrate the genes that were significantly downregulated by pre-miR-222 and pre-miR-25, respectively (see Tables I and II for full gene 
Table I. All significantly downregulated genes in pre-miR-222 treated cells compared to cells treated with negative control pre-miRs.

\begin{tabular}{|c|c|c|c|c|}
\hline RefSeq & $\begin{array}{c}\text { Gene } \\
\text { symbol }\end{array}$ & Gene assignment & Fold change & $\begin{array}{l}\text { P-value } \\
\text { (FDR) }\end{array}$ \\
\hline NM_015913 & TXNDC12 & $\begin{array}{l}\text { Thioredoxin domain containing } 12 \\
\text { (endoplasmic reticulum) }\end{array}$ & -4.807 & $1.02 \mathrm{E}-07$ \\
\hline NM_000700 & ANXA1 & Annexin A1 & -3.881 & 2.24E-08 \\
\hline NM_052886 & MAL2 & Mal, $T$ cell differentiation protein 2 & -3.681 & $1.16 \mathrm{E}-07$ \\
\hline NM_005139 & ANXA3 & Annexin A3 & -3.595 & $1.48 \mathrm{E}-09$ \\
\hline NM_004493 & HSD17B 10 & Hydroxysteroid (17-beta) dehydrogenase 10 & -3.548 & $3.73 \mathrm{E}-10$ \\
\hline NM_001124 & $\mathrm{ADM}^{\mathrm{b}}$ & Adrenomedullin & -3.526 & $1.08 \mathrm{E}-09$ \\
\hline NM_020373 & ANO2 & Anoctamin 2 & -3.475 & $1.68 \mathrm{E}-07$ \\
\hline NM_000782 & CYP24A1 & Cytochrome P450, family 24 , subfamily A, polypeptide 1 & -3.321 & $1.71 \mathrm{E}-06$ \\
\hline NM_005238 & ETS $1^{\mathrm{b}}$ & $\begin{array}{l}\text { V-ets erythroblastosis virus E26 oncogene } \\
\text { homolog } 1 \text { (avian) }\end{array}$ & -3.159 & $2.16 \mathrm{E}-08$ \\
\hline NM_003494 & DYSF & $\begin{array}{l}\text { Dysferlin, limb girdle muscular dystrophy } 2 \mathrm{~B} \\
\text { (autosomal recessive) }\end{array}$ & -3.057 & $8.62 \mathrm{E}-09$ \\
\hline NM_019026 & TMCO1 & Transmembrane and coiled-coil domains 1 & -2.935 & $4.46 \mathrm{E}-07$ \\
\hline NM_007257 & PNMA2 & Paraneoplastic antigen MA2 & -2.916 & 4.12E-08 \\
\hline NM_031302 & GLT8D2 & Glycosyltransferase 8 domain containing 2 & -2.853 & $1.19 \mathrm{E}-07$ \\
\hline NM_002371 & MAL & Mal, $\mathrm{T}$ cell differentiation protein & -2.830 & 4.19E-08 \\
\hline NM_001165 & BIRC3 & Baculoviral IAP repeat-containing 3 & -2.734 & $6.86 \mathrm{E}-08$ \\
\hline NM_153020 & $\mathrm{RBM} 24^{\mathrm{b}}$ & RNA binding motif protein 24 & -2.717 & $1.34 \mathrm{E}-05$ \\
\hline NM_020651 & PELI1 & Pellino homolog 1 (Drosophila) & -2.668 & 4.42E-06 \\
\hline NM_020455 & GPR126 & G protein-coupled receptor 126 & -2.659 & $9.57 \mathrm{E}-08$ \\
\hline NM_004572 & PKP2 & Plakophilin 2 & -2.630 & $7.81 \mathrm{E}-10$ \\
\hline NM_012431 & SEMA3E & $\begin{array}{l}\text { Sema domain, immunoglobulin domain (Ig), } \\
\text { short basic doma in, secreted, (semaphorin) } 3 \mathrm{E}\end{array}$ & -2.625 & $1.83 \mathrm{E}-05$ \\
\hline NM_002780 & PSG4 & Pregnancy specific beta-1-glycoprotein 4 & -2.606 & 8.80E-08 \\
\hline NM_002764 & PRPS1 & Phosphoribosyl pyrophosphate synthetase 1 & -2.599 & $1.99 \mathrm{E}-08$ \\
\hline NM_014322 & OPN3 & Opsin 3 & -2.581 & $9.04 \mathrm{E}-07$ \\
\hline NM_013322 & SNX10 & Sorting nexin 10 & -2.569 & $2.18 \mathrm{E}-07$ \\
\hline NM_182757 & RNF144B & Ring finger 144B & -2.519 & $1.61 \mathrm{E}-09$ \\
\hline NM_000716 & C4BPB & Complement component 4 binding protein beta & -2.519 & $6.66 \mathrm{E}-05$ \\
\hline NM_020127 & TUFT1 & Tuftelin 1 & -2.519 & $3.51 \mathrm{E}-08$ \\
\hline NM_001008749 & RAB19 & RAB19, member RAS oncogene family & -2.501 & 8.91E-07 \\
\hline NM_017439 & PION & Pigeon homolog (Drosophila) & -2.499 & $3.05 \mathrm{E}-05$ \\
\hline NM_018639 & WSB2 & WD repeat and SOCS box-containing 2 & -2.482 & 4.86E-08 \\
\hline NM_014143 & CD274 & CD274 molecule & -2.420 & $5.96 \mathrm{E}-07$ \\
\hline NM_003246 & THBS1 & Thrombospondin 1 & -2.403 & $1.78 \mathrm{E}-08$ \\
\hline NM_001159 & AOX1 & Aldehyde oxidase 1 & -2.403 & $2.50 \mathrm{E}-06$ \\
\hline NM_000141 & FGFR2 & Fibroblast growth factor receptor 2 & -2.394 & $2.56 \mathrm{E}-06$ \\
\hline NM_003901 & SGPL1 & Sphingosine-1-phosphate lyase 1 & -2.380 & $1.82 \mathrm{E}-06$ \\
\hline NM_002296 & LBR & Lamin B receptor & -2.368 & $2.36 \mathrm{E}-08$ \\
\hline NM_025239 & PDCD1LG2 & Programmed cell death 1 ligand 2 & -2.360 & 7.42E-06 \\
\hline NM_004741 & NOLC1 & Nucleolar and coiled-body phosphoprotein 1 & -2.351 & $6.16 \mathrm{E}-07$ \\
\hline NM_002998 & $\mathrm{SDC}^{\mathrm{a}}$ & Syndecan 2 & -2.333 & 2.69E-07 \\
\hline NM_001259 & $\mathrm{CDK}^{\mathrm{c}}$ & Cyclin-dependent kinase 6 & -2.332 & $2.46 \mathrm{E}-07$ \\
\hline NM_016147 & PPME1 & Protein phosphatase methylesterase 1 & -2.326 & $1.44 \mathrm{E}-08$ \\
\hline NM_004482 & GALNT3 & $\begin{array}{l}\text { UDP-N-acetyl-alpha-D-galactosamine: polypeptide } \\
\text { N-acetylgalactosaminyltransferase } 3 \text { (GalNAc-T3) }\end{array}$ & -2.314 & $4.48 \mathrm{E}-06$ \\
\hline NM_021069 & SORBS2 & Sorbin and SH3 domain containing 2 & -2.314 & 2.89E-07 \\
\hline NM_005264 & GFRA1 & GDNF family receptor alpha 1 & -2.304 & 5.49E-07 \\
\hline NM_022131 & CLSTN2 & Calsyntenin 2 & -2.298 & 7.38E-08 \\
\hline NM_002875 & RAD51 & RAD51 homolog (RecA homolog, E. coli) (S. cerevisiae) & -2.295 & 2.71E-06 \\
\hline ВС066649 & C1orf198 & Chromosome 1 open reading frame 198 & -2.275 & 2.03E-07 \\
\hline
\end{tabular}


Table I. Continued.

\begin{tabular}{|c|c|c|c|c|}
\hline RefSeq & $\begin{array}{l}\text { Gene } \\
\text { symbol }\end{array}$ & Gene assignment & Fold change & $\begin{array}{l}\text { P-value } \\
\text { (FDR) }\end{array}$ \\
\hline AK 131040 & LOC388022 & Hypothetical gene supported by AK131040 & -2.259 & $8.18 \mathrm{E}-05$ \\
\hline BC016278 & LOH3CR2A & Loss of heterozygosity, 3 , chromosomal region 2 , gene A & -2.243 & 0.0004969 \\
\hline NM_001554 & CYR61 & Cysteine-rich, angiogenic inducer, 61 & -2.241 & $6.15 \mathrm{E}-07$ \\
\hline NM_033393 & FHDC1 & FH2 domain containing 1 & -2.237 & $3.51 \mathrm{E}-07$ \\
\hline NM_002492 & NDUFB5 & NADH dehydrogenase (ubiquinone) 1 beta subcomplex, 5 & -2.225 & $1.36 \mathrm{E}-07$ \\
\hline NM_018327 & SPTLC3 & Serine palmitoyltransferase, long chain base subunit 3 & -2.225 & $6.97 \mathrm{E}-07$ \\
\hline NM_080670 & SLC35A4 & Solute carrier family 35, member A4 & -2.211 & $6.39 \mathrm{E}-07$ \\
\hline NM_022772 & EPS8L2 & EPS8-like 2 & -2.202 & 3.77E-08 \\
\hline NM_014391 & ANKRD1 & Ankyrin repeat domain 1 (cardiac muscle) & -2.191 & 7.78E-08 \\
\hline NM_016206 & VGLL3 & Vestigial like 3 (Drosophila) & -2.191 & 8.67E-07 \\
\hline $\begin{array}{l}\text { Ensembl no: } \\
\text { ENST00000319426 }\end{array}$ & - & Partially transcribed sequence & -2.188 & 4.57E-06 \\
\hline NM_004694 & SLC16A6 & $\begin{array}{l}\text { Solute carrier family } 16 \text {, member } 6 \\
\text { (monocarboxylic acid transporter } 7 \text { ) }\end{array}$ & -2.184 & 0.0003082 \\
\hline NM_021623 & PLEKHA2 & $\begin{array}{l}\text { Pleckstrin homology domain containing, family A } \\
\text { (phosphoinositide binding specific) member } 2\end{array}$ & -2.160 & $1.74 \mathrm{E}-06$ \\
\hline NR_002836 & PGM5P2 & Phosphoglucomutase 5 pseudogene 2 & -2.159 & $2.55 \mathrm{E}-07$ \\
\hline NM_001145204 & LOC729993 & $\begin{array}{l}\text { Hypothetical protein LOC729993, } \\
\text { transcript variant } 1, \text { mRNA }\end{array}$ & -2.148 & 2.73E-07 \\
\hline NM_153345 & TMEM139 & Transmembrane protein 139 & -2.143 & $3.58 \mathrm{E}-06$ \\
\hline NR_002836 & PGM5P2 & Phosphoglucomutase 5 pseudogene 2 & -2.141 & 4.39E-08 \\
\hline NM_006252 & PRKAA2 & Protein kinase, AMP-activated, alpha 2 catalytic subunit & -2.137 & 7.04E-07 \\
\hline NM_002547 & OPHN1 & Oligophrenin 1 & -2.137 & $2.60 \mathrm{E}-07$ \\
\hline NM_016132 & MYEF2 & Myelin expression factor 2 & -2.136 & $4.39 \mathrm{E}-05$ \\
\hline NM_003813 & ADAM21 & ADAM metallopeptidase domain 21 & -2.121 & 0.0005355 \\
\hline $\begin{array}{l}\text { Ensembl no: } \\
\text { ENST00000384701 }\end{array}$ & - & Expressed sequence tag (EST) & -2.116 & 0.0002848 \\
\hline NM_145753 & PHLDB2 & Pleckstrin homology-like domain, family B, member 2 & -2.099 & 4.55E-05 \\
\hline NM_001415 & EIF2S3 & $\begin{array}{l}\text { Eukaryotic translation initiation factor } 2 \\
\text { subunit } 3 \text { gamma, } 52 \mathrm{kDa}\end{array}$ & -2.096 & 2.72E-07 \\
\hline NM_000331 & SAA1 & Serum amyloid A1 & -2.086 & 0.0041182 \\
\hline NM_003265 & TLR3 & Toll-like receptor 3 & -2.082 & $5.79 \mathrm{E}-05$ \\
\hline NM_006389 & HYOU1 & Hypoxia up-regulated 1 & -2.077 & $1.02 \mathrm{E}-07$ \\
\hline NM_015238 & WWC1 & WW and $\mathrm{C} 2$ domain containing 1 & -2.069 & $1.56 \mathrm{E}-07$ \\
\hline NM_001001522 & TAGLN & Transgelin & -2.056 & $9.60 \mathrm{E}-07$ \\
\hline $\begin{array}{l}\text { Ensembl no: } \\
\text { ENST00000322446 }\end{array}$ & - & Partially transcribed sequence & -2.042 & 0.0007311 \\
\hline NM_006832 & FERMT2 & Fermitin family homolog 2 (Drosophila) & -2.005 & $3.07 \mathrm{E}-05$ \\
\hline NM_018728 & MYO5C & Myosin VC & -2.003 & $9.51 \mathrm{E}-07$ \\
\hline NM_002354 & EPCAM & Epithelial cell adhesion molecule & -2.018 & 0.0224988 \\
\hline
\end{tabular}

aPredicted target in miRanda, PicTar and TargetScan; ${ }^{b}$ predicted target in PicTar and TargetScan; ${ }^{c}$ predicted target in TargetScan.

lists). The PANTHER database was used to perform gene ontology analysis on these pre-miR target lists. This analysis illustrated that the two miRNAs target genes of diverse functions in the thyroid cells, as no pathway was significantly over- or under-represented in either list. This observation concurs with other studies on miRNA target prediction and elucidation (20-22). miR-222 and miR-25 target lists were also cross-referenced with in silico prediction results from three prediction algorithms: miRanda, PicTar and TargetScan.
Overexpression of miR-222 in Nthy-ori cells. Five of the 82 genes (6.1\%) significantly downregulated by miR-222 overexpression in the Nthy-ori 3-1 cells were predicted gene targets of the miRNA in miRanda, PicTar or TargetScan, or a combination of the databases. Gene ontology analysis revealed that no molecular function or biological process was significantly over- or underrepresented in the miR-222 target list. Notwithstanding this observation, several genes that were found to be targets of this miRNA have interesting 
A
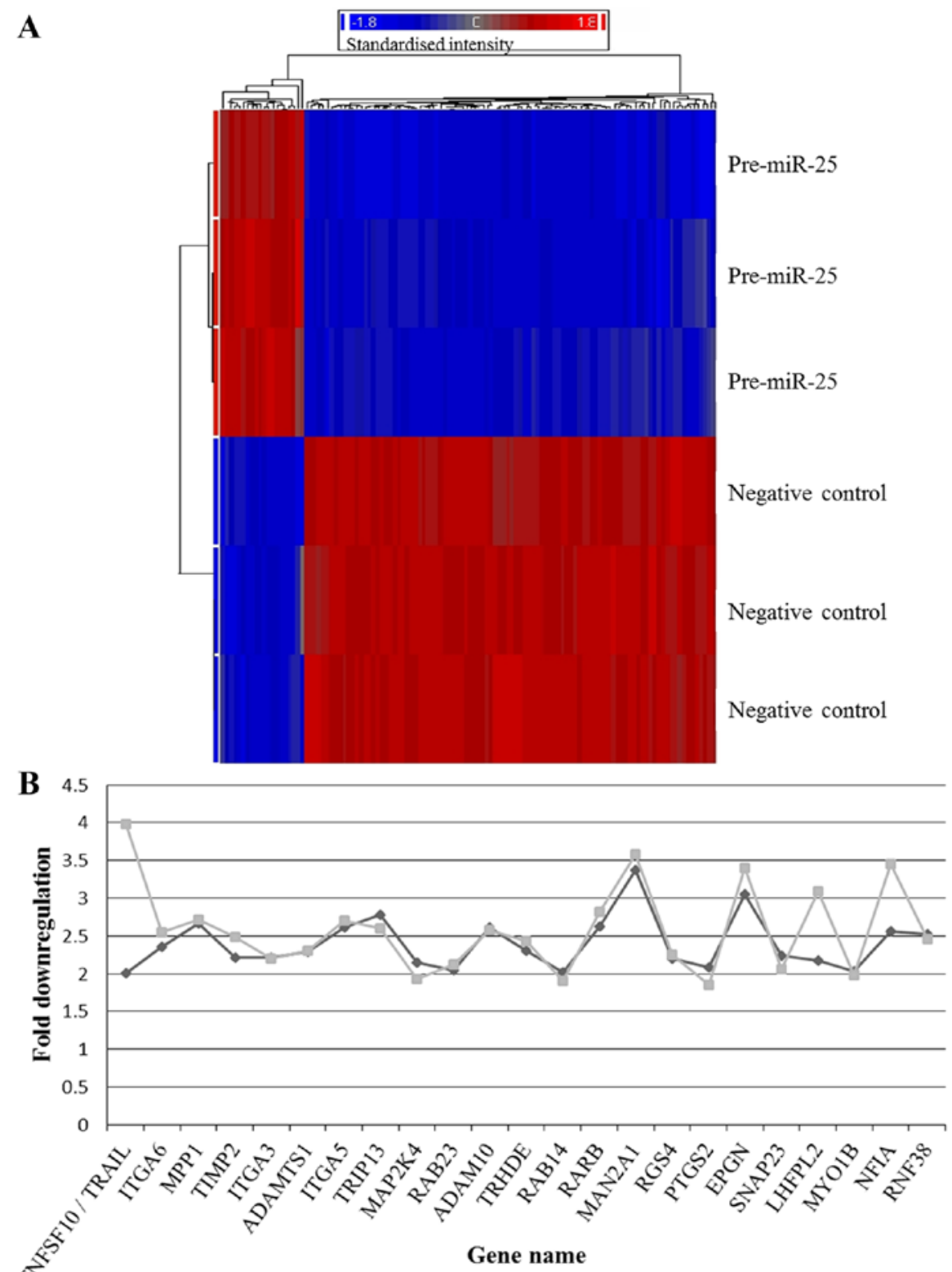

$\rightarrow$ Microarray fold downregulation $\rightarrow$-Fluidigm fold downregulation

C

Negative

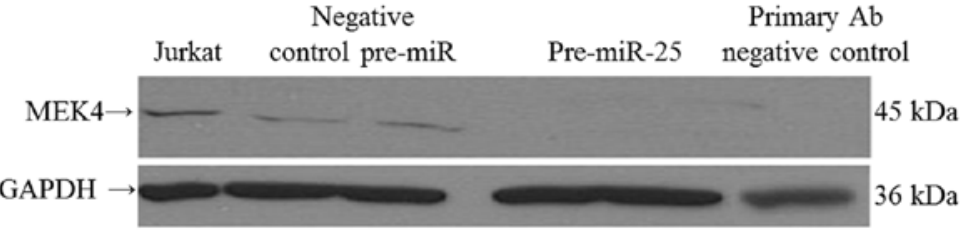

D

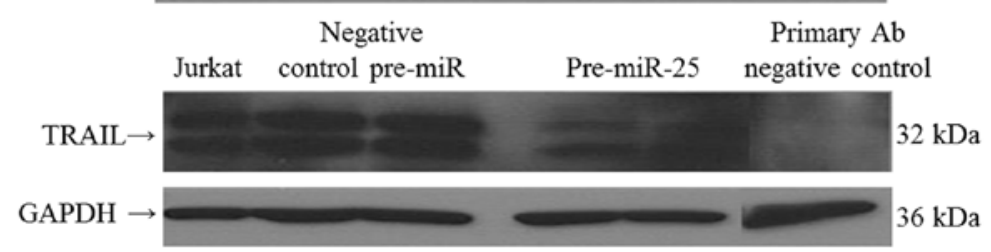

Figure 2. miR-25 regulated genes. (A) Heat map of the significantly differentially regulated genes in pre-miR-25 treated $8505 \mathrm{C}$ cells compared to negative control treated cells; false discovery rate (FDR) $\leq 0.05$ and fold-change $\geq 2$. A clear separation can be seen between the genes in pre-miR treated samples compared to negative control treated samples. (B) Line graph of the microarray and Fluidigm fold downregulation of the 23 genes validated by real-time PCR. All genes validated were found to be downregulated by both real-time PCR and microarray analyses [Pearson's correlation, 0.538 , TNF-related apoptosis-inducing ligand (TRAIL) removed, 0.810]. (C) Western blotting results for mitogen-activated protein kinase kinase 4 (MEK4) expression in 8505C cells. Jurkat T cell lysate acts as a positive control for expression of MEK4. There are two lanes where protein from negative control and pre-miR-25 transfected cells was loaded, and untreated $8505 \mathrm{C}$ protein was loaded and acted as a 'no primary antibody' negative control as it was only exposed to secondary antibody. GAPDH acts as a loading control. A band of the correct size for MEK4 (45 kDa) was detected on the blot. The reduction of MEK4 in the pre-miR- 25 treated cells successfully validates the fact that pre-miR-25 decreases the expression of this protein. (D) Western blotting results for TRAIL expression in 8505C cells. Lane titles are the same as the previous blot. Bands of approximately the correct size for TRAIL ( $32 \mathrm{kDa}$ ) were detected in the cell lysates tested. The reduction of TRAIL in the pre-miR-25 treated cells successfully validates the fact that pre-miR-25 decreases the expression of this protein. 
Table II. All significantly downregulated genes in pre-miR-25 treated cells compared to cells treated with negative control pre-miRs.

\begin{tabular}{|c|c|c|c|c|}
\hline RefSeq & $\begin{array}{l}\text { Gene } \\
\text { symbol }\end{array}$ & Gene assignment & $\begin{array}{l}\text { Fold } \\
\text { change }\end{array}$ & $\begin{array}{c}\text { P-value } \\
\text { (FDR) }\end{array}$ \\
\hline NM_000210 & ITGA6 & Integrin alpha 6 & -2.352 & $6.17 \mathrm{E}-09$ \\
\hline NM_002372 & MAN2A $1^{\mathrm{b}}$ & Mannosidase, alpha, class 2A, member 1 & -3.370 & $4.98 \mathrm{E}-10$ \\
\hline NM_002436 & MPP1 & Membrane protein, palmitoylated 1 & -2.669 & $1.08 \mathrm{E}-09$ \\
\hline NM_003255 & TIMP2 & TIMP metallopeptidase inhibitor 2 & -2.218 & $1.75 \mathrm{E}-09$ \\
\hline NM_021913 & $\mathrm{AXL}^{\mathrm{d}}$ & AXL receptor tyrosine kinase & -2.594 & $2.49 \mathrm{E}-09$ \\
\hline NM_015881 & DKK3 & Dickkopf homolog 3 (Xenopus laevis) & -3.428 & $2.89 \mathrm{E}-09$ \\
\hline NM_018442 & IQWD1 ${ }^{\mathrm{c}}$ & IQ motif and WD repeats 1 & -2.134 & 2.97E-09 \\
\hline NM_002204 & ITGA3 & Integrin alpha 3 (antigen CD49C, alpha 3 subunit of VLA-3 receptor) & -2.209 & 7.00E-09 \\
\hline NM_004035 & ACOX1 & Acyl-Coenzyme A oxidase 1, palmitoyl & -2.206 & $1.42 \mathrm{E}-08$ \\
\hline NM_005562 & LAMC2 & Laminin gamma 2 & -2.803 & $1.12 \mathrm{E}-08$ \\
\hline NM_006520 & DYNLT3 $^{\mathrm{d}}$ & Dynein, light chain, Tctex-type 3 & -2.694 & $1.07 \mathrm{E}-08$ \\
\hline NM_006988 & ADAMTS1 & ADAM metallopeptidase with thrombospondin type 1 motif 1 & -2.285 & $1.34 \mathrm{E}-08$ \\
\hline NM_006080 & SEMA3 $\mathrm{A}^{\mathrm{e}}$ & $\begin{array}{l}\text { Sema domain, immunoglobulin domain (Ig), } \\
\text { short basic domain, secreted, (semaphorin) } 3 \mathrm{~A}\end{array}$ & -2.450 & $2.61 \mathrm{E}-08$ \\
\hline NM_000351 & STS & Steroid sulfatase (microsomal), isozyme $\mathrm{S}$ & -2.410 & $2.36 \mathrm{E}-08$ \\
\hline NM_019004 & ANKIB1 & Ankyrin repeat and IBR domain containing 1 & -2.304 & $1.15 \mathrm{E}-08$ \\
\hline NM_181659 & NCOA3 & Nuclear receptor coactivator 3 & -2.006 & $1.41 \mathrm{E}-08$ \\
\hline NM_002844 & PTPRK & Protein tyrosine phosphatase receptor type $\mathrm{K}$ & -2.152 & $1.97 \mathrm{E}-08$ \\
\hline NM_002205 & ITGA5 $^{\mathrm{a}}$ & Integrin alpha 5 (fibronectin receptor, alpha polypeptide) & -2.614 & $9.07 \mathrm{E}-09$ \\
\hline NM_000916 & OXTR & Oxytocin receptor & -2.473 & 4.16E-08 \\
\hline NM_005349 & RBPJ & $\begin{array}{l}\text { Recombination signal binding protein for immunoglobulin } \\
\text { kappa J region }\end{array}$ & -2.033 & $4.83 \mathrm{E}-08$ \\
\hline NM_005471 & GNPDA1 & Glucosamine-6-phosphate deaminase 1 & -2.236 & $1.42 \mathrm{E}-08$ \\
\hline NM_004237 & TRIP13 & Thyroid hormone receptor interactor 13 & -2.781 & $1.02 \mathrm{E}-08$ \\
\hline NM_001418 & EIF4G2 ${ }^{\mathrm{e}}$ & Eukaryotic translation initiation factor 4 gamma, 2 & -2.494 & $1.95 \mathrm{E}-08$ \\
\hline NM_021999 & ITM2B & Integral membrane protein $2 \mathrm{~B}$ & -2.070 & $3.95 \mathrm{E}-08$ \\
\hline NM_000138 & $\mathrm{FBN}^{\mathrm{b}}$ & Fibrillin 1 & -2.355 & $2.18 \mathrm{E}-07$ \\
\hline NM_003010 & MAP2K $4^{\mathrm{b}}$ & Mitogen-activated protein kinase kinase 4 & -2.147 & $1.34 \mathrm{E}-08$ \\
\hline NM_016275 & SELT & Selenoprotein $\mathrm{T}$ & -3.175 & $2.35 \mathrm{E}-08$ \\
\hline NM_001102445 & RGS4 & Regulator of G-protein signaling 4 & -2.194 & $3.62 \mathrm{E}-08$ \\
\hline NM_001001521 & $\mathrm{UGP}^{\mathrm{b}}$ & UDP-glucose pyrophosphorylase 2 & -3.032 & $6.61 \mathrm{E}-08$ \\
\hline NM_002948 & RPL15 & Ribosomal protein L15 & -2.659 & 4.97E-08 \\
\hline NM_003139 & $\mathrm{SRPR}^{\mathrm{b}}$ & Signal recognition particle receptor ('docking protein') & -2.195 & $1.33 \mathrm{E}-07$ \\
\hline NM_001190 & $\mathrm{BCAT}^{\mathrm{b}}$ & Branched chain aminotransferase 2, mitochondrial & -3.040 & $7.52 \mathrm{E}-08$ \\
\hline NM_000693 & ALDH1A3 & Aldehyde dehydrogenase 1 family, member A3 & -2.168 & $2.58 \mathrm{E}-06$ \\
\hline NM_012242 & DKK1 & Dickkopf homolog 1 (Xenopus laevis) & -2.060 & $3.20 \mathrm{E}-07$ \\
\hline NM_006178 & NSF & N-ethylmaleimide-sensitive factor & -2.202 & $4.09 \mathrm{E}-07$ \\
\hline NM_199511 & CCDC80 & Coiled-coil domain containing 80 & -2.016 & $1.25 \mathrm{E}-07$ \\
\hline NM_014674 & EDEM1 ${ }^{\mathrm{b}}$ & ER degradation enhancer, mannosidase alpha-like 1 & -2.391 & $8.84 \mathrm{E}-08$ \\
\hline NM_213611 & SLC25A3 & Solute carrier family 25 (mitochondrial carrier; phosphate carrier) & -2.086 & $1.17 \mathrm{E}-07$ \\
\hline NM_133494 & NEK7 & NIMA (never in mitosis gene a)-related kinase 7 & -2.424 & $3.00 \mathrm{E}-07$ \\
\hline NM_017958 & PLEKHB2 & $\begin{array}{l}\text { Pleckstrin homology domain containing, family B2 } \\
\text { (evectins) member }\end{array}$ & -3.420 & $8.84 \mathrm{E}-08$ \\
\hline NM_000259 & MYO5A & Myosin VA (heavy chain 12, myoxin) & -2.426 & $2.11 \mathrm{E}-07$ \\
\hline NM_016277 & RAB $23^{\mathrm{b}}$ & RAB23, member RAS oncogene family & -2.051 & $1.26 \mathrm{E}-07$ \\
\hline NM_001110 & ADAM10 & ADAM metallopeptidase domain 10 & -2.616 & $3.21 \mathrm{E}-07$ \\
\hline NM_001693 & ATP6V1B2 & ATPase, $\mathrm{H}^{+}$transporting, lysosomal $56 / 58 \mathrm{kDa}, \mathrm{V} 1$ subunit $\mathrm{B} 2$ & -2.064 & $1.30 \mathrm{E}-07$ \\
\hline NM_005779 & LHFPL2 $^{\mathrm{a}}$ & Lipoma HMGIC fusion partner-like 2 & -2.173 & $1.72 \mathrm{E}-07$ \\
\hline NM_016422 & RNF141 e & Ring finger protein 141 & -2.260 & 8.57E-08 \\
\hline NM_002095 & GTF2E2 & General transcription factor IIE, polypeptide 2 , beta $34 \mathrm{k}$ & -2.570 & $7.22 \mathrm{E}-07$ \\
\hline NM_003483 & $\mathrm{HMGA}^{\mathrm{e}}$ & High mobility group AT-hook 2 & -2.654 & $1.24 \mathrm{E}-07$ \\
\hline NM_014223 & $\mathrm{NFYC}^{\mathrm{c}}$ & Nuclear transcription factor $\mathrm{Y}$, gamma & -2.112 & $1.57 \mathrm{E}-07$ \\
\hline NM_013381 & TRHDE & Thyrotropin-releasing hormone degrading enzyme & -2.306 & $2.96 \mathrm{E}-07$ \\
\hline NM_006287 & TFPI & $\begin{array}{l}\text { Tissue factor pathway inhibitor (lipoprotein-associated } \\
\text { coagulation inhibitor) }\end{array}$ & -2.145 & $5.36 \mathrm{E}-07$ \\
\hline NM_033540 & MFN1 & Mitofusin 1 & -2.014 & $3.46 \mathrm{E}-07$ \\
\hline
\end{tabular}


Table II. Continued.

\begin{tabular}{|c|c|c|c|c|}
\hline RefSeq & $\begin{array}{c}\text { Gene } \\
\text { symbol }\end{array}$ & Gene assignment & $\begin{array}{l}\text { Fold } \\
\text { change }\end{array}$ & $\begin{array}{l}\text { P-value } \\
\text { (FDR) }\end{array}$ \\
\hline NM_024664 & $\mathrm{PPCS}^{\mathrm{b}}$ & Phosphopantothenoylcysteine synthetase & -2.386 & $3.87 \mathrm{E}-07$ \\
\hline NM_023080 & C8orf33 & Chromosome 8 open reading frame 33 & -2.006 & $1.98 \mathrm{E}-07$ \\
\hline NM_016352 & CPA4 & Carboxypeptidase A4 & -2.060 & $1.26 \mathrm{E}-06$ \\
\hline NM_012223 & MYO1B $^{b}$ & Myosin IB & -2.030 & $1.35 \mathrm{E}-06$ \\
\hline NM_020223 & FAM20C & Family with sequence similarity 20 member C & -2.387 & $1.16 \mathrm{E}-06$ \\
\hline NM_004670 & PAPSS2 & 3'-phosphoadenosine 5'-phosphosulfate synthase 2 & -2.347 & $9.66 \mathrm{E}-07$ \\
\hline NM_005896 & IDH1 & Isocitrate dehydrogenase $1\left(\mathrm{NADP}^{+}\right)$, soluble & -2.599 & $3.89 \mathrm{E}-06$ \\
\hline NM_016322 & RAB14 ${ }^{\mathrm{b}}$ & RAB 14, member RAS oncogene family & -2.021 & 4.30E-07 \\
\hline NM_002971 & SATB1 & SATB homeobox 1 & -2.080 & $1.43 \mathrm{E}-06$ \\
\hline NM_000405 & GM2A & GM2 ganglioside activator & -2.249 & $4.07 \mathrm{E}-07$ \\
\hline NM_001547 & IFIT2 & Interferon-induced protein with tetratricopeptide repeats & -4.287 & $8.87 \mathrm{E}-07$ \\
\hline NM_016570 & ERGIC2 & ERGIC and golgi 2 & -2.858 & 9.73E-07 \\
\hline NM_005595 & NFIA $^{\mathrm{b}}$ & Nuclear factor I/A & -2.567 & $6.45 \mathrm{E}-07$ \\
\hline NM_005981 & TSPAN31 & Tetraspanin 31 & -2.127 & $6.55 \mathrm{E}-07$ \\
\hline NM_001085471 & FOXN3 & Forkhead box N3 & -2.314 & $1.11 \mathrm{E}-06$ \\
\hline ВC016048 & LRRC38 & Leucine rich repeat containing 38 & -2.394 & $5.78 \mathrm{E}-07$ \\
\hline NM_005314 & GRPR & Gastrin-releasing peptide receptor & -2.545 & $6.82 \mathrm{E}-06$ \\
\hline NM_002783 & PSG7 & Pregnancy specific beta-1-glycoprotein 7 & -2.015 & 3.89E-06 \\
\hline NM_002781 & PSG5 & Pregnancy specific beta-1-glycoprotein 5 & -2.222 & 4.73E-06 \\
\hline NM_003884 & KAT2B & $\mathrm{K}$ (lysine) acetyltransferase $2 \mathrm{~B}$ & -2.108 & $4.43 \mathrm{E}-06$ \\
\hline NM_001040409 & MTHFD2 & $\begin{array}{l}\text { Methylenetetrahydrofolate dehydrogenase (NADP }{ }^{+} \\
\text {dependent) 2, methenyltetrahydrofolate cyclohydrolase }\end{array}$ & -2.312 & $1.92 \mathrm{E}-05$ \\
\hline NM_003580 & $\mathrm{NSMAF}^{\mathrm{b}}$ & $\begin{array}{l}\text { Neutral sphingomyelinase (N-SMase) } \\
\text { activation associated factor }\end{array}$ & -2.072 & $2.33 \mathrm{E}-06$ \\
\hline NM_001013442 & EPGN & Epithelial mitogen homolog (mouse) & -3.057 & $1.89 \mathrm{E}-06$ \\
\hline NM_012319 & SLC39A6 & Solute carrier family 39 (zinc transporter), member 6 & -2.026 & $2.95 \mathrm{E}-06$ \\
\hline NM_000965 & RARB & Retinoic acid receptor, beta & -2.624 & $5.42 \mathrm{E}-06$ \\
\hline NM_152772 & TCP11L2 & T-complex 11 (mouse)-like 2 & -2.105 & 4.63E-05 \\
\hline ВC017297 & FAM49B & Family with sequence similarity 49 member B & -2.051 & $1.87 \mathrm{E}-06$ \\
\hline NM_001002265 & MARCH8 & Membrane-associated ring finger $(\mathrm{C} 3 \mathrm{HC} 4) 8$ & -2.232 & 7.22E-06 \\
\hline NM_015509 & NECAP $1^{\mathrm{b}}$ & NECAP endocytosis associated 1 & -2.013 & $1.85 \mathrm{E}-06$ \\
\hline NM_001080512 & BICC1 & Bicaudal C homolog 1 (Drosophila) & -2.193 & $9.59 \mathrm{E}-06$ \\
\hline NM_001031850 & PSG6 & Pregnancy specific beta-1-glycoprotein 6 & -2.806 & 7.76E-06 \\
\hline NM_020841 & OSBPL8 & Oxysterol binding protein-like 8 & -2.135 & 8.37E-06 \\
\hline NM_007036 & ESM1 & Endothelial cell-specific molecule 1 & -2.059 & $5.81 \mathrm{E}-06$ \\
\hline NM_016075 & VPS36 & Vacuolar protein sorting 36 homolog (S. cerevisiae) & -2.021 & $3.55 \mathrm{E}-06$ \\
\hline NM_000963 & PTGS2 & $\begin{array}{l}\text { Prostaglandin-endoperoxide synthase } 2 \\
\text { (prostaglandin G/H synthase and cyclooxygenase) }\end{array}$ & -2.084 & $9.13 \mathrm{E}-06$ \\
\hline NM_017946 & FKBP14 & FK506 binding protein $14,22 \mathrm{kDa}$ & -2.240 & $1.13 \mathrm{E}-05$ \\
\hline NM_003825 & SNAP23 & Synaptosomal-associated protein, $23 \mathrm{kDa}$ & -2.233 & $6.08 \mathrm{E}-06$ \\
\hline NM_194328 & RNF38 ${ }^{\mathrm{a}}$ & Ring finger protein 38 & -2.526 & 7.91E-06 \\
\hline NM_006636 & MTHFD2 & $\begin{array}{l}\text { Methylenetetrahydrofolate dehydrogenase }\left(\mathrm{NADP}^{+}\right. \\
\text {dependent) } 2 \text {, methenyltetrahydrofolate cyclohydrolase }\end{array}$ & -2.362 & 0.0001745 \\
\hline NM_006905 & PSG1 & Pregnancy specific $\beta$-1-glycoprotein 1 & -2.016 & 0.0001079 \\
\hline $\begin{array}{l}\text { Ensembl no: } \\
\text { ENST00000390952 }\end{array}$ & - & Expressed Sequence Tag (EST) & -2.078 & 0.0001661 \\
\hline NM_030920 & $\mathrm{ANP} 32 \mathrm{E}^{\mathrm{e}}$ & $\begin{array}{l}\text { Acidic (leucine-rich) nuclear } \\
\text { phosphoprotein } 32 \text { family, member E }\end{array}$ & -2.663 & $6.01 \mathrm{E}-05$ \\
\hline NM_000262 & NAGA & N-acetylgalactosaminidase, alpha & -2.055 & 4.77E-05 \\
\hline NM_001548 & IFIT1 & Interferon-induced protein with tetratricopeptide repeats & -2.439 & $3.00 \mathrm{E}-05$ \\
\hline NM_001039569 & AP1S3 & Adaptor-related protein complex 1, sigma 3 subunit & -2.193 & 0.0003395 \\
\hline NM_003810 & TNFSF10 & Tumour necrosis factor (ligand) superfamily, member 10 & -2.003 & 0.0011012 \\
\hline
\end{tabular}

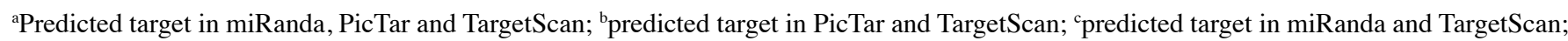
predicted target in miRanda; ${ }^{\mathrm{e}}$ predicted target in TargetScan. 
Table III. Downregulated genes following expression of pre-miR-222 in Nthy-ori 3-1.

\begin{tabular}{|c|c|c|c|c|}
\hline Gene & $\begin{array}{l}\text { Microarray fold } \\
\text { downregulation }\end{array}$ & $\begin{array}{c}\text { Microarray } \\
\text { P-value (FDR) }\end{array}$ & $\begin{array}{l}\text { Fluidigm qPCR fold } \\
\text { downregulation }\end{array}$ & $\begin{array}{c}\text { Fluidigm } \\
\text { P-value (t-test) }\end{array}$ \\
\hline$M A L 2$ & 3.681 & $1.16 \mathrm{E}-07$ & 3.314 & $3.55 \mathrm{E}-05$ \\
\hline$M A L$ & 2.83 & 4.19E-08 & 2.332 & $1.54 \mathrm{E}-05$ \\
\hline$T L R 3$ & 2.082 & 5.79E-05 & 2.341 & 0.0001 \\
\hline$A D M^{\mathrm{a}}$ & 3.526 & $1.08 \mathrm{E}-09$ & 3.81 & 2.93E-05 \\
\hline$R A B 19$ & 2.501 & 8.91E-07 & 3.7 & 4.48E-06 \\
\hline$P D C D 1 L G 2$ & 2.36 & 7.42E-06 & 1.827 & 0.004 \\
\hline$R A D 51$ & 2.295 & 2.71E-06 & 1.597 & $9.59 \mathrm{E}-05$ \\
\hline$A D A M 21$ & 2.121 & 0.0005 & 1.008 & 0.9517 \\
\hline HYOU1 & 2.077 & $1.02 \mathrm{E}-07$ & 1.198 & 0.0001 \\
\hline THBS1 & 2.403 & $1.78 \mathrm{E}-08$ & 1.769 & 0.0002 \\
\hline$E T S 1^{\mathrm{a}}$ & 3.159 & $2.16 \mathrm{E}-08$ & 2.208 & 0.0003 \\
\hline CYR61 & 2.241 & $6.15 \mathrm{E}-07$ & 1.745 & 0.0006 \\
\hline PHLDB2 & 2.099 & $4.55 \mathrm{E}-05$ & 1.178 & 0.003 \\
\hline BIRC3 & 2.734 & $6.86 \mathrm{E}-08$ & 2.406 & 0.0005 \\
\hline PRKAA2 & 2.137 & 7.04E-07 & 1.595 & 0.001 \\
\hline CYP24AI & 3.321 & $1.71 \mathrm{E}-06$ & 1.911 & 0.0006 \\
\hline$A O X 1$ & 2.403 & $2.50 \mathrm{E}-06$ & 2.024 & 0.0006 \\
\hline MYO5C & 2.003 & $9.51 \mathrm{E}-07$ & 3.549 & 0.0002 \\
\hline GPR126 & 2.659 & $9.57 \mathrm{E}-08$ & 3.24 & $6.8 \mathrm{E}-05$ \\
\hline$C D K 6^{\mathrm{b}}$ & 2.332 & $2.46 \mathrm{E}-07$ & 1.588 & 0.0004 \\
\hline PPME1 & 2.326 & $1.44 \mathrm{E}-08$ & 1.5 & 0.0006 \\
\hline$R B M 24^{\mathrm{a}}$ & 2.717 & $1.34 \mathrm{E}-05$ & 3.55 & $3.11 \mathrm{E}-06$ \\
\hline
\end{tabular}

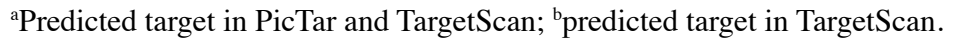

molecular functions. For instance, seven receptors are in the lists (MAL, OPN3, PSG4, FGFR2, GPR126, TLR3 and LBR), four transcription factors (PSG4, ETS1, MAL and RBM24), five signalling molecules (THBS1, ETS1, CYR61, SEMA3E and $A D M)$, and five genes involved in defence and immunity (PNMA2, C4BPB, SDC2, MAL, TLR3 and SAA1).

The downregulation of 22 genes in response to $\mathrm{miR}-222$ overexpression identified by the microarray analysis (both predicted and novel targets) was successfully validated using Fluidigm real-time PCR technologies (Table III and Fig. 1B) (Pearson's correlation, 0.506).

Overexpression of $\mathrm{miR}-25$ in $8505 \mathrm{C}$ cells. The list of $98 \mathrm{miR}-25$ target genes was also cross-referenced with in silico prediction results. This comparison revealed that the list of genes that were significantly downregulated by pre-miR-25 in the $8505 \mathrm{C}$ cells is enriched with $27 / 98$ or $27.55 \%$ predicted gene targets for miR-25. Gene ontology analysis of the miR-25 gene target list suggests that cell adhesion is an important aspect of miR-25 functioning in the thyroid cells as biological processes including cell adhesion, cell communication, signal transduction, and cell adhesion-mediated signalling were significantly enriched for in this list (P-value 1.47E-02, 1.18E-03, 3.13E-02 and 1.59E-02, respectively). The list is also significantly enriched for cell adhesion molecules: ITGA3, ITGA5 (which is also a predicted target of the miRNA in all three databases used); and ITGA6 (P-value 3.10E-03) and CAM family adhesion molecules: PSG1,
PSG5, PSG6 and PSG7 (P-value 2.47E-02). Seven receptors are also in the miR-25 list: TCP11L2, RARB, GRPR, PTPRK, $A X L, L R R C 38$ and $O X T R$; six transcription factors: $R A R B$, FOXN3, SATB1, NCOA3, GTF2E2 and NFIA; and five kinases: $M P P 1, A X L, M A P 2 K 4, P A P S S 2$ and NEK7, and a member of the tumour necrosis family, TNFSF10/TRAIL.

Fluidigm real-time PCR technologies were used to confirm the downregulation of 23 predicted and novel gene targets in response to miR-25 expression in the $8505 \mathrm{C}$ cells (Table IV and Fig. 2B). All genes tested were downregulated in both the microarray and Fluidigm analyses (Pearson's correlation, 0.538; TRAIL removed, 0.810). In addition, two novel targets of miR-25 were successfully validated at the protein level by western blotting; predicted target MEK4 and novel target TRAIL. Fig. 2C and D illustrate the reduction in MEK4 and TRAIL protein expression following treatment of anaplastic thyroid cells with pre-miR-25, demonstrating that they are direct or indirect targets of this miRNA.

\section{Discussion}

The aim of this study was to elucidate the mRNA targets of two miRNAs that we had previously found to be differentially expressed in thyroid cancer (5): miR-222 and miR-25. This was achieved by overexpressing the thyroid cancer-associated miRNA miR-222 in the transformed normal Nthy-ori cells, and miR-25 in the anaplastic cancer-derived $8505 \mathrm{C}$ cells. 
Table IV. Downregulated genes following expression of pre-miR-25 in 8505C cells.

\begin{tabular}{|c|c|c|c|c|}
\hline Gene & $\begin{array}{l}\text { Microarray fold } \\
\text { downregulation }\end{array}$ & $\begin{array}{c}\text { Microarray } \\
\text { P-value (FDR) }\end{array}$ & $\begin{array}{c}\text { Fluidigm qPCR fold } \\
\text { downregulation }\end{array}$ & $\begin{array}{c}\text { Fluidigm } \\
\text { P-value (t-test) }\end{array}$ \\
\hline TNFSF10/TRAIL & 2.003 & 0.001 & 3.982 & 0.003 \\
\hline ITGA6 & 2.352 & $6.17 \mathrm{E}-09$ & 2.552 & 0.0002 \\
\hline MPP1 & 2.669 & $1.08 \mathrm{E}-09$ & 2.718 & 7.3E-06 \\
\hline TIMP2 & 2.218 & $1.75 \mathrm{E}-09$ & 2.483 & $2.19 \mathrm{E}-05$ \\
\hline ITGA3 & 2.209 & 7.00E-09 & 2.194 & $2.40 \mathrm{E}-07$ \\
\hline ADAMTS1 & 2.285 & $1.34 \mathrm{E}-08$ & 2.304 & 0.002 \\
\hline ITGA $^{\mathrm{b}}$ & 2.614 & 9.07E-09 & 2.699 & $4.68 \mathrm{E}-07$ \\
\hline TRIP13 & 2.781 & $1.02 \mathrm{E}-08$ & 2.606 & 4.92E-06 \\
\hline MAP2K $4^{\mathrm{a}}$ & 2.147 & $1.34 \mathrm{E}-08$ & 1.925 & $7.70 \mathrm{E}-05$ \\
\hline $\mathrm{RAB}^{2} 3^{\mathrm{a}}$ & 2.051 & $1.26 \mathrm{E}-07$ & 2.122 & $8.45 \mathrm{E}-05$ \\
\hline ADAM10 ${ }^{\mathrm{a}}$ & 2.616 & $3.21 \mathrm{E}-07$ & 2.571 & $1.57 \mathrm{E}-05$ \\
\hline TRHDE & 2.306 & $2.96 \mathrm{E}-07$ & 2.43 & $2.09 \mathrm{E}-06$ \\
\hline RAB $14^{\mathrm{a}}$ & 2.021 & $4.30 \mathrm{E}-07$ & 1.907 & 2.91E-05 \\
\hline RARB & 2.624 & 5.42E-06 & 2.816 & $7.68 \mathrm{E}-06$ \\
\hline MAN2A1 ${ }^{a}$ & 3.37 & $4.98 \mathrm{E}-10$ & 3.576 & 2.19E-07 \\
\hline RGS4 & 2.194 & 3.62E-08 & 2.255 & 0.0009 \\
\hline PTGS2 & 2.084 & $9.13 \mathrm{E}-06$ & 1.853 & 0.0098 \\
\hline EPGN & 3.057 & $1.89 \mathrm{E}-06$ & 3.394 & 0.0003 \\
\hline SNAP23 & 2.233 & $6.08 \mathrm{E}-06$ & 2.057 & $8.58 \mathrm{E}-05$ \\
\hline${\text { LHFPL } 2^{\mathrm{b}}}$ & 2.173 & 1.72E-07 & 3.092 & 0.0002 \\
\hline MYO1B $^{\mathrm{a}}$ & 2.03 & $1.35 \mathrm{E}-06$ & 1.986 & $1.997 \mathrm{E}-06$ \\
\hline NFIA $^{\mathrm{a}}$ & 2.567 & $6.45 \mathrm{E}-07$ & 3.445 & 0.015 \\
\hline
\end{tabular}

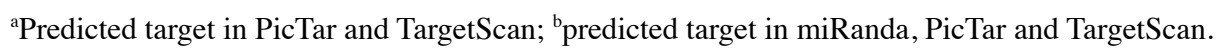

The use of microarrays to analyse the RNA from these cells exploited an unbiased genome-wide approach and yielded the discovery of a set of mRNAs that are either directly or indirectly targeted by each miRNA in thyroid cells, and have not been previously described.

The gene target lists produced by this genome-wide investigation compare favourably with previously published studies on miRNA target elucidation and prediction. Similar to prior studies $(21,23)$, the two pre-miRs used in this body of study each downregulated almost 100 target transcripts: 98 by pre-miR-25 in the $8505 \mathrm{C}$ cells and 82 by pre-miR-222 in the Nthy-ori 3-1 cells. The subtle change in gene expression observed in the genes targeted by pre-miR-222 and pre-miR-25 (between 2- and 4 -fold) is also similar to other studies on the subject $(6,21)$. Finally, the relatively low number of predicted miRNA targets significantly differentially expressed has been noted previously (6), and the divergent assortment of molecular functions and biological processes encompassed within the gene target lists is also reflective of published accounts of target prediction and elucidation $(20,21)$. These diverse lists allow us insight into the functions of these two miRNAs within the respective thyroid cell lines. For instance, upregulation of miR-222 in Nthy-ori cells impacts on several transcription factors, cell signalling molecules, and genes involved in defence and immunity (PNMA2, C4BPB, SDC2, MAL, TLR3 and SAA1).
Expression of miR-25 is downregulated in anaplastic thyroid carcinoma, so we upregulated the expression of miR-25 in the anaplastic thyroid carcinoma $8505 \mathrm{C}$ cell line. Although miR-25 was found to target genes with a wide variety of functions, the gene ontology analysis of this list highlights the predilection of this miRNA for regulating genes involved in cell adhesion, with both this cellular process and molecules of this molecular function being significantly over-represented in this list. Two main groups of cell adhesion molecules are over-represented in the miR-25 target list; integrin $\alpha$ genes ITGA3, ITGA5 (which is a predicted target of the miR-25 in miRanda, PicTar and TargetScan) and ITGA6, and the pregnancy-specific glycoproteins (PSGs); PSG1, PSG5, PSG6 and PSG7. Loss of miR-25 expression in anaplastic thyroid carcinoma is therefore associated with upregulation of genes encoding integrins and glycoproteins. The ITGA genes appear to be markers of aggression in the cancers in which they have been explored. For instance, ITGA3 and ITGA5 have been shown to be markers of invasiveness in head and neck squamous cell carcinoma (24), ITGA3, along with ITGB4 and 5 were found to be candidate biomarkers for cervical lymph node metastasis or death in tongue squamous cell carcinoma (25) and ITGA6 was found to be necessary for the tumourigenicity of a stem cell-like subpopulation within the MCF7 breast cancer cell line (26). 
This is not the first occasion miR-25 has been linked to a role in cell adhesion, as Xu et al have previously highlighted the role of miR-25 in oesophageal squamous cell carcinoma (ESCC). They found upregulation of this miRNA in ESCC cells promoted migration and invasion, and also found that miR-25 directly targets E-Cadherin, an important cellular adhesion protein in the ESCC cells (13). Gerson et al have recently identified miR-25, and indeed miR-222, to be responsive to $\beta 4$ integrin expression in breast carcinoma cell lines (27). Our observation, along with these previous studies in breast cancer and ESCC, indicates a role for miR-25 in tumour progression through the disruption of cell adhesion.

Additional functions of miR-25 are highlighted with the two proteins (MEK4 and TRAIL) that were shown to be downregulated in response to the expression of miR-25. MEK4 is a member of the MAP kinase kinase family that directly phosphorylates and activates c-Jun NH2-terminal kinase (JNK) in response to cellular stresses and pro-inflammatory cytokines, and can also activate p38 (28). MAP kinase signalling is often disrupted in thyroid cancer through $R A S, B R A F$ or $R E T / P T C$ mutations (29). Both tumour suppressor and oncogenic functions have been attributed to MEK4 in cancer (30,31). Little is known of the role of MEK4 in thyroid cancer; however, Chiariello et al demonstrated that Ret signalling involves MEK4 (32). It remains unclear as to whether MEK4 expression influences anaplastic thyroid carcinoma in a tumour suppressive or oncogenic manner. However, as pre-miR-25 was shown to downregulate MEK4 mRNA and protein in ATC 8505C cells in this study, it is interesting to speculate that the endogenous downregulation of miR-25 may lead to the upregulation of MEK4 expression and its pro-oncogenic characteristics in ATC cells.

TRAIL expression was also decreased in response to miR-25 expression in $8505 \mathrm{C}$ cells. TRAIL has five cellular receptors and can activate the extrinsic and intrinsic pathways to regulate intercellular apoptotic responses in the immune system (33). Approximately a decade and a half ago it was noted that TRAIL could induce apoptosis in transformed and malignant cells but not in normal cells (34). TRAIL was subsequently found to be capable of triggering apoptosis in eight PTC and two ATC derived thyroid carcinoma cell lines but not in normal thyrocytes (35). As a result of this tumour-specific effect, a great deal of work was done to develop anticancer therapies to mimic the effect of TRAIL. The TRAIL and MAP kinase pathways appear to overlap in TRAIL therapy signalling. Ohtsuka et al reported that the combination of anti-death receptor antibodies and chemotherapy agents led to a synergistic activation of the JNK/p38 MAP kinase which was mediated by MEK4 in breast, prostate and colon cancer cells (36). Moreover, Söderström et al showed that MAP/extracellular regulated kinase (ERK) signalling (which is frequently over-activated in thyroid cancer) protected activated $\mathrm{T}$ cells from TRAIL-induced apoptosis (37).

miR-25 involvement in the TRAIL-mediated apoptosis pathway was confirmed further with the observation by Razumilava et al that this miRNA targets TRAIL death receptor-4 (DR4) and promotes apoptosis resistance in cholangiocarcinoma (38). If one considers the pro-apoptotic role of TRAIL, it is difficult to elucidate how an upregulation of this gene through the endogenous downregulation of miR-25 would be beneficial to the progress of anaplastic thyroid carcinoma. However, a review by Newsom-Davis et al outlines in vitro and in vivo experiments in which TRAIL expression induced proliferation, migration and invasion of tumour cells which were resistant to TRAIL-mediated apoptosis. They describe how secondary intracellular signalling complexes, following TRAIL DISC formation, can activate NF- $\mathrm{B}$ via the inhibitor of $\kappa \mathrm{B}$ kinase complex (IKK complex) which signals through MAPK, JNK and p38 (39). Other groups have shown that TRAIL-induced survival and proliferation does not involve the p38 kinase pathway but is dependent on the MAP kinase ERKs. Therefore, in the anaplastic thyroid cancer cells, the endogenous downregulation of miR-25 may enable the upregulation of TRAIL to activate its pro-survival MAP kinase responses (perhaps involving MEK4). Future studies may also benefit from investigating whether miR-25 is involved in regulating MEK4 and TRAIL in response to TRAIL cancer therapies.

In conclusion, this study used an unbiased approach to elucidate almost 100 genes that are either directly or indirectly targeted by miR-25 and miR-222 in thyroid cells. The number of genes in these target lists, the extent to which the genes are regulated and the diversity of their functions is reflective of other published accounts of miRNA target prediction and elucidation. The gene targets of these two miRNAs confirm the diverse nature of miRNA-target interactions within cells. A considerable proportion of these targets have been validated using RT-PCR with a further two, MEK4 and TRAIL, being confirmed at the protein level. We provide an interesting insight into the functions of these two miRNAs in thyroid cells, in particular that cell adhesion and apoptosis are important aspects of miR-25 functioning in thyroid cells. In addition to this, there is broad scope for further investigation of the many results produced by this study.

\section{Acknowledgements}

The authors would like to acknowledge grants from the Health Research Board Molecular Medicine PhD training programme and the Science Foundation Ireland funded Molecular Therapeutics for Cancer Ireland.

\section{References}

1. Smallridge RC, Marlow LA and Copland JA: Anaplastic thyroid cancer: molecular pathogenesis and emerging therapies. Endocr Relat Cancer 16: 17-44, 2009.

2. He H, Jazdzewski K, Li W, Liyanarachchi S, Nagy R, Volinia S, Calin GA, Liu CG, Franssila K, Suster S, et al: The role of microRNA genes in papillary thyroid carcinoma. Proc Natl Acad Sci USA 102: 19075-19080, 2005.

3. Pallante P, Visone R, Ferracin M, Ferraro A, Berlingieri MT, Troncone G, Chiappetta G, Liu CG, Santoro M, Negrini M, et al: MicroRNA deregulation in human thyroid papillary carcinomas. Endocr Relat Cancer 13: 497-508, 2006.

4. Nikiforova MN, Tseng GC, Steward D, Diorio D and Nikiforov YE: MicroRNA expression profiling of thyroid tumors: biological significance and diagnostic utility. J Clin Endocrinol Metab 93: 1600-1608, 2008.

5. Aherne ST, Smyth PC, Flavin RJ, Russell SM, Denning KM, Li JH, Guenther SM, O'Leary JJ and Sheils OM: Geographical mapping of a multifocal thyroid tumour using genetic alteration analysis and miRNA profiling. Mol Cancer 7: 89, 2008.

6. Kim HJ, Kim YH, Lee DS, Chung J-K and Kim S: In vivo imaging of functional targeting of miR-221 in papillary thyroid carcinoma. J Nucl Med 49: 1686-1693, 2008. 
7. Mitomo S, Maesawa C, Ogasawara S, Iwaya T, Shibazaki M, Yashima-Abo A, Kotani K, Oikawa H, Sakurai E, Izutsu N, et al: Downregulation of miR-138 is associated with overexpression of human telomerase reverse transcriptase protein in human anaplastic thyroid carcinoma cell lines. Cancer Sci 99: 280-286, 2008.

8. Keutgen XM, Filicori F, Crowley MJ, Wang Y, Scognamiglio T, Hoda R, Buitrago D, Cooper D, Zeiger MA, Zarnegar R, et al: A panel of four miRNAs accurately differentiates malignant from benign indeterminate thyroid lesions on fine needle aspiration. Clin Cancer Res 18: 2032-2038, 2012.

9. Chou CK, Yang KD, Chou FF, Huang CC, Lan YW, Lee YF, Kang HY and Liu RT: Prognostic implications of miR-146b expression and its functional role in papillary thyroid carcinoma. J Clin Endocrinol Metab 98: E196-E205, 2013.

10. Visone R, Russo L, Pallante P, De Martino I, Ferraro A, Leone V, Borbone E, Petrocca F, Alder H, Croce CM and Fusco A: MicroRNAs (miR)-221 and miR-222, both overexpressed in human thyroid papillary carcinomas, regulate $\mathrm{p} 27^{\mathrm{Kipl}}$ protein levels and cell cycle. Endocr Relat Cancer 14: 791-798, 2007.

11. Petrocca F, Vecchione A and Croce CM: Emerging role of miR-106b-25/miR-17-92 clusters in the control of transforming growth factor beta signaling. Cancer Res 68: 8191-8194, 2008.

12. Kim Y-K, Yu J, Han TS, Park SY, Namkoong B, Kim DH, Hur K, Yoo MW, Lee HJ, Yang HK and Kim VN: Functional links between clustered microRNAs: Suppression of cell-cycle inhibitors by microRNA clusters in gastric cancer. Nucleic Acids Res 37: 1672-1681, 2009.

13. Xu X, Chen Z, Zhao X, Wang J, Ding D, Wang Z, Tan F, Tan X, Zhou F, Sun J, et al: MicroRNA-25 promotes cell migration and invasion in esophageal squamous cell carcinoma. Biochem Biophys Res Commun 421: 640-645, 2012.

14. Zhang H, Zuo Z, Lu X, Wang L, Wang H and Zhu Z: MiR-25 regulates apoptosis by targeting Bim in human ovarian cancer. Oncol Rep 27: 594-598, 2012.

15. Kan T, Sato F, Ito T, Matsumura N, David S, Cheng Y, Agarwal R, Paun BC, Jin Z, Olaru AV, et al: The miR-106b-25 polycistron, activated by genomic amplification, functions as an oncogene by suppressing p21 and Bim. Gastroenterology 136: 1689-1700, 2009.

16. Visone R, Pallante P, Vecchione A, Cirombella R, Ferracin M, Ferraro A, Volinia S, Coluzzi S, Leone V, Borbone E, et al: Specific microRNAs are downregulated in human thyroid anaplastic carcinomas. Oncogene 26: 7590-7595, 2007.

17. Esposito F, Tornincasa M, Pallante P, Federico A, Borbone E, Pierantoni GM and Fusco A: Down-regulation of the miR-25 and miR-30d contributes to the development of anaplastic thyroid carcinoma targeting the polycomb protein EZH2. J Clin Endocrinol Metab 97: E710-E718, 2012.

18. Livak KJ and Schmittgen TD: Analysis of relative gene expression data using real-time quantitative PCR and the 2(-Delta Delta C(T)) Method. Methods 25: 402-408, 2001.

19. Irizarry RA, Hobbs B, Collin F, Beazer-Barclay YD, Antonellis KJ Scherf U and Speed TP: Exploration, normalization, and summaries of high density oligonucleotide array probe level data. Biostatistics 4: 249-264, 2003.

20. Lewis BP, Shih IH, Jones-Rhoades MW, Bartel DP and Burge CB: Prediction of mammalian microRNA targets. Cell 115: 787-798, 2003.

21. Lim LP, Lau NC, Garrett-Engele P, Grimson A, Schelter JM, Castle J, Bartel DP, Linsley PS and Johnson JM: Microarray analysis shows that some microRNAs downregulate large numbers of target mRNAs. Nature 433: 769-773, 2005.

22. Bartel DP: MicroRNAs: target recognition and regulatory functions. Cell 136: 215-233, 2009.
23. Brennecke J, Stark A, Russell RB and Cohen SM: Principles of microRNA-target recognition. PLoS Biol 3: e85, 2005.

24. Yu YH, Kuo HK and Chang KW: The evolving transcriptome of head and neck squamous cell carcinoma: a systematic review. PLoS One 3: e3215, 2008.

25. Kurokawa A, Nagata M, Kitamura N, Noman AA, Ohnishi M, Ohyama T, Kobayashi T, Shingaki S and Takagi R; Oral, Maxillofacial Pathology, and Surgery Group: Diagnostic value of integrin alpha3, beta4, and beta5 gene expression levels for the clinical outcome of tongue squamous cell carcinoma. Cancer 112: 1272-1281, 2008

26. Cariati M, Naderi A, Brown JP, Smalley MJ, Pinder SE, Caldas C and Purushotham AD: Alpha-6 integrin is necessary for the tumourigenicity of a stem cell-like subpopulation within the MCF7 breast cancer cell line. Int J Cancer 122: 298-304, 2008.

27. Gerson KD, Maddula VSRK, Seligmann BE, Shearstone JR, Khan A and Mercurio AM: Effects of $\beta 4$ integrin expression on microRNA patterns in breast cancer. Biol Open 1: 658-666, 2012.

28. Cuenda A: Mitogen-activated protein kinase kinase 4 (MKK4). Int J Biochem Cell Biol 32: 581-587, 2000.

29. Fagin JA and Mitsiades N: Molecular pathology of thyroid cancer: diagnostic and clinical implications. Best Pract Res Clin Endocrinol Metab 22: 955-969, 2008.

30. Wang L, Pan Y and Dai JL: Evidence of MKK4 pro-oncogenic activity in breast and pancreatic tumors. Oncogene 23: 5978-5985, 2004.

31. Xin W, Yun KJ, Ricci F, Zahurak M, Qiu W, Su GH, Yeo CJ, Hruban RH, Kern SE and Iacobuzio-Donahue CA: MAP2K4/ MKK4 expression in pancreatic cancer: genetic validation of immunohistochemistry and relationship to disease course. Clin Cancer Res 10: 8516-8520, 2004.

32. Chiariello M, Visconti R, Carlomagno F, Melillo RM, Bucci C, de Franciscis V, Fox GM, Jing S, Coso OA, Gutkind JS, et al: Signalling of the Ret receptor tyrosine kinase through the c-Jun NH2-terminal protein kinases (JNKS): evidence for a divergence of the ERKs and JNKs pathways induced by Ret. Oncogene 16: 2435-2445, 1998.

33. Mahalingam D, Szegezdi E, Keane M, de Jong S and Samali A: TRAIL receptor signalling and modulation: are we on the right TRAIL? Cancer Treat Rev 35: 280-288, 2009.

34. Ashkenazi A and Dixit VM: Apoptosis control by death and decoy receptors. Curr Opin Cell Biol 11: 255-260, 1999.

35. Mitsiades N, Poulaki V, Tseleni-Balafouta S, Koutras DA and Stamenkovic I: Thyroid carcinoma cells are resistant to FAS-mediated apoptosis but sensitive to tumor necrosis factorrelated apoptosis-inducing ligand. Cancer Res 60: 4122-4129, 2000.

36. Ohtsuka T, Buchsbaum D, Oliver P, Makhija S, Kimberly R and Zhou T: Synergistic induction of tumor cell apoptosis by death receptor antibody and chemotherapy agent through JNK/p38 and mitochondrial death pathway. Oncogene 22: 2034-2044, 2003.

37. Söderström TS, Poukkula M, Holmström TH, Heiskanen KM and Eriksson JE: Mitogen-activated protein kinase/extracellular signal-regulated kinase signaling in activated $\mathrm{T}$ cells abrogates TRAIL-induced apoptosis upstream of the mitochondrial amplification loop and caspase-8. J Immunol 169: 2851-2860, 2002.

38. Razumilava N, Bronk SF, Smoot RL, Fingas CD, Werneburg NW, Roberts LR and Mott JL: miR-25 targets TNF-related apoptosis inducing ligand (TRAIL) death receptor- 4 and promotes apoptosis resistance in cholangiocarcinoma. Hepatology 55: 465-475, 2012

39. Newsom-Davis T, Prieske $\mathrm{S}$ and Walczak H: Is TRAIL the holy grail of cancer therapy? Apoptosis 14: 607-623, 2009. 